\title{
Educators Role on the Challenges of Education and Technology in Global and Local Era
}

\author{
Anabelie V. Valdez \\ Mindanao State University \\ Main Campus, Marawi City, Philippines \\ anabelievillavaldez@gmail.com
}

\begin{abstract}
The world has become very competitive, and quality education is a global concern. Countries in the top are not just meeting the needs of its citizens but engaging them to innovation, providing their people with quality education and resources to re-invent themselves in the 21 st century. In the Philippines context, enhancing the attainments of quality education is one of its primary concerns. The issue on quality education has become the pivot point for many universities and other institutions in the educational system even across the globe. Knowing the challenge of global competitiveness, educators play a significant role in meeting those challenges to attain quality education especially in this era of technological age. Educators should take their roles in empowering people to enhance their knowledge and skills that could influence the societies to become globally competitive.
\end{abstract}

Keywords: educators, quality education, challenges, globalization

\section{INTRODUCTION}

The unending challenge of education is its quality improvement. Laying down the foundation for change at the same time attuning the best qualities of the present and for the future is very important to improve continuously the quality of education. Education can never be a neutral process. The balance between objective "facts" and questioning these facts represents a great challenge to the professional teacher (ETUCE, 2002). We need to improve not only the quality of education but also the quality of training and provide state of the art facilities in order for us to compete globally. World Bank reiterates that lack of quality is the major problem in many education systems. UNESCO's "International Commission on Education for the Twenty-first Century" concluded in their report that "a greater focus on quality is desirable everywhere, even in countries where all children are enrolled in basic education.

Quality education is the foundation for globalization and it should start locally that is - in the classroom. In order to reach at the top level, we must ensure that the foundation is tough and influences significantly whatever the changes and challenges of education and technology. Education and technology is indispensable and complex system. Nevertheless, it does not mean that in its absence, quality of education may jeopardize. There are three dimensions constituting the global environment - global, national and local - that have to be considered in building a higher performing university (Marginson \& Sawir, 2006). These dimensions are a challenge to the educational sectors.

Despite progress has been made, but challenges of education is infinite and continuous. Change is impossible without learning and learning is impossible without change. As such, we must try to redirect education towards sustainability, that is, towards a new way of doing things in order to improve the quality of education and identify the specific challenges that higher education faces. Educators play a crucial role in all challenges of education both in local and global era. Challenges of education and technology in global and local era emanate in the classroom.

Thus, educators has great role on the challenges that we faced today in our education system. The great challenge of educators is how to converge and integrate the emerging change in education and technology in imparting knowledge and skills to the students. The challenge includes the designing of instructional material and teachers' pedagogical content knowledge that could prepare the students for global competitiveness. As such, this paper presents different perspectives on the role of educators to the challenges of education.

\section{THEORETICAL FRAMEWORK}

\section{Challenges in Global and Local Era}

Quality education is crucial if we want to become globally competitive. Today's globalization requires countries to nurture pools of well-educated workers who are able to perform complex tasks and adapt rapidly to their changing environment and the evolving needs in the global and local areas. The importance of quality of education should be continuous. Schwartzman (2010) said that the factors that influence the effectiveness of education management reformation include human resources, facilities, financial resources, technology, environment, department structure, management and leadership. Figure 1 below show a conceptual diagram on the challenges of education presented in this paper.

Globalization is multidimensional, involving a large number of integrated components operating together and characterized by continuous changes. In this paper, I considered globalization as a major and global challenge of education. Current trends show that it is exploding every nation in a very high speed. Global issues challenge higher education every day and it is important to address the impacts of globalization on education.

$$
\text { Globalization is identical to }
$$
internationalization, referring to the emergent interconnectedness and interdependence among institutions and people around the world. Technology, 
economics, politics, education and cultural exchanges are key elements for globalization, in advances in technology greatly influence to each element.

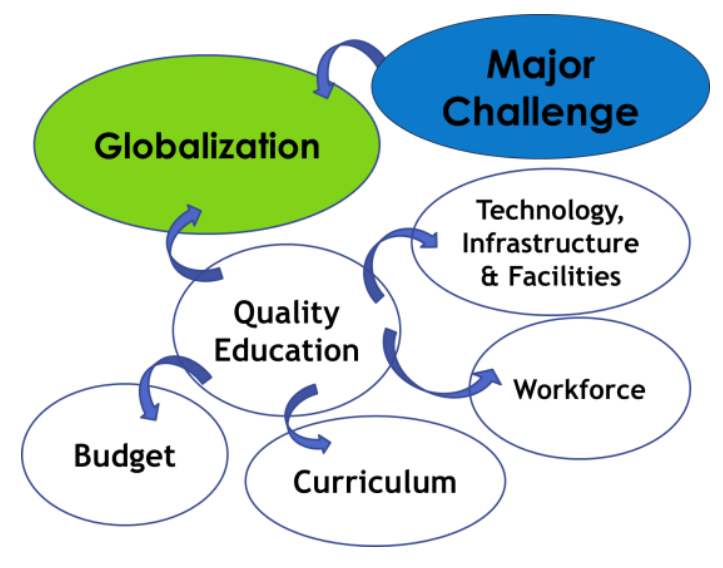

Figure 1

Conceptual Diagram on the Challenges of Education

However, the bottom line for globalization is quality education (Butucha, 2012). This quality education is the primary concern of the educators in local era. Institutions could not compete globally if its quality education is at stake. To attain quality education we have to consider the budget, the curriculum, the technology, infrastructure and facilities, and the workforce. In fact, Salmi (2009) pointed out some salient features to consider in becoming a World Class University and generally, it includes the concentration of talents, abundant resources, and favorable governance.

In local perspectives, teaching is tangible in attaining quality education and no solo teaching style will suit to the needs of the learners' ability to learn. Teachers' pedagogical content knowledge is crucial in the delivery of instructions in the curriculum. The most important thing in teaching is to encourage and allow the learners to assess their needs and direct their learning. According to Quirk (1994), teaching varies from teacher to teacher the same way that learning varies from and among learners. When teachers designed activities in class is in accordance to the learners' ability, meaningful and successful teachinglearning process will be accomplished.

\section{Educators Role on the Challenges of Education}

This paper pointed out six challenges of education to address the major challenge, which is the globalization. In each challenge, educators have corresponding roles to play.

\section{Globalization}

In global point of view, I consider globalization as the major challenge of education. The implication of globalization makes it necessary to reform our education systems; for it requires us to adapt our own education content to meet not only our local demands, but also our international concerns. Globalization in education started during the colonial era, which geared towards nationalization of colonial education system in every country by the colonial pow- ers. Today, globalization in education is influence greatly by continuous emergence of technologies and strategies in providing quality education.

The global competitive efforts are driven by intentions to pursue the highest level of nation building programs especially in the development of technology, economics, and educational efforts (Damme, 2001). To survive within this condition, educators must be proactive in improving capacities to provide people with best education environment and services massively (Jahan \& Jespersen, 2015; UNESCO, 2006). Educators should address the global competitiveness challenge by establishing a lifelong system of knowledge development, skills and competencies to facilitate innovation, social development and economic growth (Dahlman, C. J., D. Zhihua Zeng, and S. Wang (2006). In the context of globalization, extent and depth networking and collaboration among educators are necessary especially among developing countries.

\section{Quality Education}

The unending challenge of education is its quality improvement. Laying down the foundation for change at the same time attuning the best qualities of the present and for the future is very important to improve continuously the quality of education. Many institutions of higher education have formed consortia for mutual objectives to attain center of excellence. University or colleges programmes, school curriculum teachers training, research, development, and technological advancement are common in networking and collaboration. Quality conveys difference in value and ethos. Continuous professional growth, quality trainings, strengthened networking, collaborations, and availability of resources are the essential keys in achieving quality education.

Granting that resources are readily available, all educational stakeholders and students in every university and institution play significant role in attaining the quality education. They must be involved in thorough planning, and in implementing the plans. Varying ideas, work force, and students is essential in achieving excellent education. Study of Kekeeva, Sardarova, and Ergakieva (2015), mentioned that modern education must be fundamental and universal, continuous and humanistic, interactive and informative in order to prepare a new class of experts competitive enough to the unending change and paradigm shifts of modern education. Education is a life-long learning and un-ending journey in the search of knowledge, innovations, and pedagogies that may encounter obstacles and environmental pressures.

\section{Budget}

Educational sectors particularly in the developing countries faced economic crisis. The economic challenges face by the education sectors hampered largely in providing quality education and global competitiveness. Budgetary appropriations are imperative particularly in using new technologies in teaching. In order to become a globalize institution resources must be readily available and properly allocated. Thus, education stakeholders particularly 
leaders in education must develop a workable financial plan putting down a micro and macro-economic stability, good governance, and well developed economic and institutional development plan.

\section{Curriculum}

Curriculum changes from time to time in order to address the demand and needs in the society. Curriculum harmonization is essential in all academic institutions. Education is the foundation for globalization and in turn, globalization influences education significantly. To become globally competitive institutions, curricular revisions and enhancement is needed to address the emerging technologies that are to be integrated. Lam (2010) pointed out that for globalization, curriculum should enhance the diversity of learning and teaching skills. Educators should let the learners experience the world of education. The curriculum should address the nature of learners and learning is changing dramatically because of the development and wide availability of the new technologies in this global world.

Frand (2000) and Tefera and Greign (2010) noted that globalization and technology have brought about fundamental changes in the ways in which we teach and students learn. In the past, the common method of learning and imparting the knowledge needed was from printed books and journals in libraries and from the lectures delivered in the classrooms. In this modern era, students can log into virtual libraries, Google through the internet, use virtual spaces for connection, collaboration and group work, participate in e-learning and m-learning courses, and join online networks that can cover the entire globe.

In this global era, interactive and collaborative learning has become a common exercise among students, teachers and other individual. In this process, the relations between learners and teachers have changed. As such, regular assessment of the school curriculum is necessary in order integrate the necessary revisions and modification as needs arise. Furthermore, educators' regular training is indispensable for them to keep abreast the on-going change brought by technological innovations.

Masse and Popovich (2006), reiterate that teachers play a critical role in the teaching/learning process and they influence varied areas like classroom behaviors, presentations, activities and approaches. It is then the role of the educators/teachers to design curriculum or instructions to meet the learners' individual differences. Chatterjee \& Ramish (2015) research findings suggest that individual have no common learning styles, thus, teachers and educators alike must explore different techniques in teaching as part of the curriculum. Exposing students to different learning activities can adopt a wider field of student learning styles in order to achieve a more effective learning.

\section{Technology, Infrastructure and Facilities}

Todays' technological advancement, access on networking and collaboration towards quality education are just a mouse click away. Establishing trust and confidence among other institutions will just matter. However, in developing countries like Philippines, particularly in education system low technology, poor infrastructure and facilities is always a challenge. We all know that integration of technology into teaching and learning is very important in order to transforms education practice by empowering students into individualize learning.

Technology, infrastructure and facilities are essential elements to provide quality teaching and learning for an institutions global competitiveness. Increase resources for teachers in teaching and trainings are a critical component to ensure appropriate and effective integration of technology in the curriculum. Information and communication technology (ICT) greatly enhance globalization. ICT has ICT has facilitated nation's massive benefit of innovation, communication and access to global information (Tefera \& Greijn, 2010).

Advancement in information technology and knowledge explosion delivers a wider opportunities in bridging the gap between the developed and developing countries. Tefera and Greijn, (2010), mentioned that information and communication technology greatly accelerate globalization. ICT attributed the increase in global trade and productivity, facilitation of business and industry expansion, and enhancement of collaboration in education and research.

In the aspect of educators' role, we need to have better understanding the time invested by teachers and students to address the educational gap. Educational leaders should optimize to equip students and teachers with the tools they need to become active and productive members of the global society.

\section{Workforce}

We need to improve not only the quality of education but also the quality of training and provide state of the art facilities in order for us to compete globally. World Bank reiterates that lack of quality is the major problem in many education systems. UNESCO's "International Commission on Education for the Twenty-first Century" concluded in their report that "a greater focus on quality is desirable everywhere, even in countries where all children are enrolled in basic education", thus, quality education and training is always attainable.

The factors that influence the effectiveness of education management reformation include human resources, facilities, financial resources, technology, environment, department structure, management and leadership (Schwartzman, 2010). Amongst these elements, researchers and practitioners claimed that human resources are the challenging issues for most organizations (Prybil, 2003) in particular for faculties (Raina \&Khatri, 2015). It was acknowledged by Ramanujam and Rousseau (2006) that workforces will face more complex demands for producing high quality services and goods than they can produce as their contribution in sustaining the existence of the enterprise during global competitive situation (Haslam, Wegge \& Postmes, 2009). Academic staff members of 
a university for instance are required to have capacities in producing high quality research products, publications, and provide life impacts to society. Thus, the organizational effectiveness in dealing with these human resources is broadly accepted as dependent upon the capacities of management and leadership of the university executives (Yukl, 2010; Welch, 2007).

Teachers must employ different instructional strategies in teaching to help the learners interact the subject being taught in a way that the learners understand it well. Giving student different opportunity to learning will help them discover their preferred learning styles, and discover their strength and weaknesses. As mentioned by Nzesei (2015) in his study, learners received information based on VAK theory in varied form such us modalities that involves visual or sight, pictures, diagrams, and symbols. Another one is through auditory (sounds, words), and kinaesthetic (taste, touch, and smell).

According to Middaugh (2009), benchmark of effective educational practice includes: 1) level of academic challenge (Course prep, quantity of readings and papers, course emphasis, campus environment emphasis), 2) student interaction with faculty members, 3) supportive campus environment, 4) active networking and collaboration, and 5) enriching educational experiences. Furthermore, job satisfaction and organizational commitment are predicted to determine the effectiveness of university management in obtaining its missions and positive performances.

However, supply of highly trained knowledge workers like teachers or educators are limited and incompetent with respect to the use of technology. As such, leaders in education should continuously provide professional growth for the teachers particularly in the development of teachers' digital competence, for them to apply digital and technological resources in teaching. Furthermore, continuous professional growth of teachers or educators will enhance their innovative and creative skills, and become more productive in their profession.

Reports on the educational outcomes indicate a substantial variation all over the world. These also varied greatly within countries, producing a wide dispersion of test scores among students (Burhanuddin, 2017). Situational elements influencing the quality of education includes, resources of the educational system, management practices, quality of educators, individual characteristics, organizational culture, family backgrounds, the availability of learning resources, and environment (UNESCO, 2006).

Teachers or educators, and leaders in education play a vital role in transmitting knowledge to the learners, and teaching should be a continuous journey of learning. Although the context of education at this era calls for globalization, it does not mean that we will ignore the important foundation of it, which are the activities transpired in the classroom. Lam (2010) said that educational globalization involves wider and broader educational opportunities for the learners and it should enhance the diversity of learning opportunities to learners in all aspect. Education sector has great role in experiencing the students in the world of education.
Educators should understand the nature of the learners and learning, and teaching is changing in accordance to the development and wide availability of the new technologies in this global world. This is the greatest role and challenge among educators and education administrators.

\section{CONCLUSION}

Success in higher education expansion caused a number of challenges. Many countries fight to deal with financial issues to attune the quality education and global competitiveness. Consequently, the quality of higher education in many countries declined (ADB, 2011). Intensifying up and intensifying out are both necessary if the quality of higher education is available to the growing number of students. There is considerably less agreement as to the appropriate balance between these agendas. While this balance may vary from country to country, the local governments need to consider key policy issues in the allocation of education resources. This enable a higher education system proportionally respond to the demands of economic growth and social concern.

Examination of the performance in many Asian countries, leads to a conclusion that university systems probably experienced constraints in responding global competitiveness. This may arise from many factors that contribute to the higher education system (Schwartzman, 2010). University governance is highlighted as one of the critical problems experienced in most higher education institutions (Welch 2007; DGHE, 2003). A number of underlying factors were identified by UNESCO (2006) and Raina and Khatri (2015) as influencing the capacity of a university to implement management reformation.

In local perspectives, even though it may not be probable to give comprehensive teaching methods as it relates to its impacts on higher education curriculum, it is still best if we face the challenge of education and technology from grassroots. The nature of learners imminent to our class in this digital era and is completely different from those previous eras and it is rapidly changing. Students of the 21 st century have varied exposure in lifestyles, and events outside their local contexts and cultural patterns. This challenges us to understand the learners from local to global cultural contexts. Globalization has brought the need for teaching inter-cultural skills, differentiated and contextualized instructions and instructional materials.

In order to move at the similar pace with the world, we need to abreast the change and begin rather than going away from the idea of globalization and its impacts on higher education curriculum. The mainstream of education aim at how to produce citizens that fit in a global lifestyle. Thus, it is vital for us teachers to acquire and update our digital literacy continuously to meet the needs of students.

Knowledge about what technology is, how it works, what purposes it can serve, and how to use and integrate in teaching efficiently and effectively to achieve specific goals is a paramount importance. This is the challenge and call of the local and global era. 
Delivery of knowledge must integrate the concepts of globalization in classroom practices. To fit and survive this local and global era, globalization and digitalization are so important. However, it requires paramount of planning, budgeting, implementing and monitoring. It is also important that curriculum policy responds to this reality by accepting and adopting the principles of globalization and integrate it into our educational practices.

\section{REFERENCES}

[1] ADB. 2011. Higher Education Across Asia: An Overview of Issues and Strategies. Manila: Asian Development Bank (ADB).

[2] Burhanuddin. 2017. Leading the University to Build a Greater Performance. The $4^{\text {th }}$ International Conference on Language, Society and Culture in Asian Contexts, KnE Social Sciences, 46-59. DOI 10.18502/kss.v1i3.724.

[3] Butucha, K. G. 2015. The Impacts of Globalization on Higher Education Curriculum: Implications for Educational Practices. Baraton Interdisciplinary Research Journal, 68-74.

[4] Chatterjee, \& Ramish. 2015. Linking Teaching Style and Learning Style as a Measure of Person Environment Fit to Assess Student Performance. Faculty At, Ibs Bangalore India. October 2015 Volume: 6 Issue: 4 Article: 04 ISSN 1309-6249.

[5] Dahlman, C. J., Zeng, D. Z., and Wang, S. 2006. Developing a System of Life Long Learning in China to Enhance Competitiveness. Washington, D.C.: World Bank.

[6] ETUCE. 2002. Quality in Education: Presentation of ETUCE's Work 1995-2001. Brussels: ETUCE.

[7] Haslam, S.A., Wegge, J., \& Postmes, T. 2009. Are We on a Learning Curve or a Treadmill? The Benefits of Participative Group Goal Setting Become Apparent as Tasks Become Increasingly Challenging IBE, EI, and UNESCO. Quality Education and the Key Role of Teachers. Retrieved August 1, 2016, from www.ibe.unesco.org.

[8] Jahan, S., \& Jespersen, E. 2015. Human Development Report 2015: Work for Human Development. New York: United Nations Development Programme.

[9] Kekeeva, Z., Sardarova, Z., \& Ergalieva, G. 2015. The Preparation of A specialist in Networking CulturalEducational Space University.

[10] Lam, Y. Y. 2010. Impact of Globalization on Higher Education: An Empirical Study of Education Policy \& Planning of Design Education in Hong Kong. International Education Studies, 3(4).

[11] Marginson, S., \& Sawir, E. 2006. University Leaderse Strategies in the Global Environment: A Comparative Study of Universitas Indonesia and the Australian National University. Higher Education, 52, 343-373.

[12] Middaugh, M. F. 2010. Assistant Vice President for Institutional Research and Planning University of Delaware Commissioner and Vice Chair Middle States Commission on Higher Education.

[13] Nzesei, M. 2015. A Correlation Study Between Learning Styles and Academic Achievement among Secondary School Students in Kenya. Nairobi: University of Nairobi.

[14] Prybil, L. D. 2003. Challenge and Opportunities Facing Health Administration Practice and Education. Journal of Healthcare Management, 48(4), 223-231.

[15] Salmi, J. 2009. The Challenge of Establishing WorldClass Universities. Washington, DC: World Bank.
[16] Schwartzman, S. 2010. Higher Education Reform: Indonesia and Latin America. Paper presented at the The International Higher Education Reform, Jakarta. Retrieved August 1, 2016, from http://www.schwartzman.org.br/simon/jakarta.htm.

[17] Quirk, M. E. 1994. How To Learn And Teach In Medical School. Springfield: Charles C. Thomas.

[18] Raina, K., \& Khatri, P. 2015. Faculty Engagement in Higher Education: Prospects and Areas of Research. Horizon, 23 (4): 285-308, https://doi.org/10.1108/OTH03-2015-0011.

[19] Teferra, D., \& Greijn, H. 2010. Higher Education and Globalization: Challenges, Threats and Opportunities for Africa. Retrieved Feb. 16, 2015, from http://www.icde.org/filestore/

Resources/Handbooks/Highereducationandg lobalization.pdf.

[20] UNESCO. 2006. Higher Education in South-East Asia. Bangkok, Thailand: Asia and Pacific Regional Bureau for Education (APEID)

[21] Welch, A. R. 2007. Blurred Vision? Public and Private Higher Education in Indonesia. Higher Education, 54(5), 665-687.

[22] Yukl, G. 2010. Leadership in organizations. Upper Saddle River, N.J: Prentice-Hall International Inc. 